\title{
Four thousand years of vegetation and fire history in the spruce forests of northern Kyrgyzstan (Kungey Alatau, Central Asia)
}

\author{
Ruth Beer · Willy Tinner
}

Received: 23 January 2007/Accepted: 28 August 2007/Published online: 26 January 2008

(C) Springer-Verlag 2008

\begin{abstract}
Analyses of pollen, macrofossils and microscopic charcoal in the sediment of a small sub-alpine lake (Karakol, Kyrgyzstan) provide new data to reconstruct the vegetation history of the Kungey Alatau spruce forest during the late-Holocene, i.e. the past 4,000 years. The pollen data suggest that Picea schrenkiana F. and M. was the dominant tree in this region from the beginning of the record. The pollen record of pronounced die-backs of the forests, along with lithostratigraphical evidence, points to possible climatic cooling (and/or drying) around 3,800 cal year B.P. and between 3,350 and 2,520 cal year B.P., with a culmination at 2,800-2,600 cal B.P., although stable climatic conditions are reported for this region for the past $3,000-4,000$ years in previous studies. From 2,500 to 190 cal year B.P. high pollen values of $P$. schrenkiana suggest rather closed and dense forests under the environmental conditions of that time. A marked decline in spruce forests occurred with the onset of modern human activities in the region from $190 \mathrm{cal}$ year B.P. These results show that the present forests are anthropogenically reduced and represent only about half of their potential natural extent. As $P$. schrenkiana is a species endemic to the western Tien Shan, it is most likely that its refugium was confined to this
\end{abstract}

Communicated by A. Lotter.

R. Beer $(\varangle) \cdot$ W. Tinner

Section of Palaeoecology, Institute of Plant Sciences, University of Bern, Altenbergrain 21, 3013 Bern, Switzerland

e-mail: ruth.beer@ips.unibe.ch

W. Tinner

Institute of Terrestrial Ecosystems,

Department of Environmental Sciences, ETH Zurich,

Universitätstrasse 16, 8092 Zurich, Switzerland region. However, our palaeoecological record is too recent to address this hypothesis thoroughly.

Keywords Picea schrenkiana - Pollen - Charcoal .

Holocene $\cdot$ Natural vegetation $\cdot$ Kyrgyzstan $\cdot$ Central Asia

\section{Introduction}

Kyrgyzstan is one of the countries in Central Asia with little forest cover, only $4.2 \%$ of the land surface (Musuraliev 1998). In wide areas of the Kyrgyzstan lowlands and mountains, steppes and subalpine and alpine meadows dominate the landscapes (Gottschling et al. 2005). Nonlinear vertical gradients of temperature and precipitation (Böhner 1996; Esper 2000) confine forest growth to a band or patches on mountain slopes (Miehe et al. 1996). The upper limit of tree growth is primarily controlled by temperature and the lower limit by precipitation (Miehe et al. 1996). The natural range of Picea schrenkiana, a species endemic to the area, is confined to the mountains north of the Naryn (Kyrgyzstan) and extends out to the ranges of the Chinese Tien Shan as far as Bogda Shan (Xinjiang) (Farjon 1990). In the region of Lake Issyk-Kul the spruce forests occur between 2,000 and 2,900 $\mathrm{m}$ a.s.l. on north-facing slopes (Gottschling 2006). The trees grow 40-50 m tall and have a straight columnar habit. They grow on various mountain soils, usually in rocky places with seepage water from snowmelt (Farjon 1990). During the Second World War great areas of the forests were cleared for fuel supply. Since the end of the war the remaining forests were protected and could recover to a certain degree. Although logging of trees was forbidden, the forests were heavily grazed, so natural regeneration was limited. It has been hypothesized that the present forest cover is only half of its 
natural potential (Gan 1982). However, in the absence of paleobotanical investigations such statements are speculative. Even though the extent of spruce forests is rather low, they have an important capacity for water retention and they inhibit erosion and landslides (Gottschling 2006).

Because of the concern for the forests in Kyrgyzstan, the Kyrgyz-Swiss Forestry Support Programme (KIRFOR), a project of Intercooperation (Switzerland) was started in 1995 with the aims of developing modern forestry management tools, promoting productive activities in forest management by the private sector and supporting adequate education and research in forest management. Started in 2003, a common research project by KIRFOR and the paleoecological group of the Institute of Plant Sciences (IPS) of the University of Bern was set up to reconstruct the Holocene vegetation and fire history of the different forest types in Kyrgyzstan, for almost nothing is known about them at present. In the context of this project special attention is paid to human impact and the natural potential of these forests. Through the record presented in this study we reconstruct the late-Holocene vegetation history, fire history and human activity on a millennial scale for a site in the spruce forests of the Kungey Alatau by means of pollen, macrofossils, lithostratigraphy, microscopic charcoal, and LOI.

\section{Materials and methods}

Study area

Karakol $\left(42^{\circ} 50^{\prime} \mathrm{N}, 77^{\circ} 23^{\prime} \mathrm{E}\right)$ is a subalpine lake located at 2,353 $\mathrm{m}$ a.s.l. on the north-facing slope of the Kungey Alatau in the Biosphere Reserve Issyk-Kul (Fig. 1). It has a surface area of 5 ha and has an outlet at its eastern border. Picea schrenkiana forms dense forests on north, east and west-facing slopes in this area. Pastures and meadows extend around the lake. Atmospheric circulation over the Issyk-Kul region is controlled by the Siberian High Pressure Cell and the Southwest Indian Low. During winter months the southwest branch of the Siberian High extends south into the Tien Shan, bringing cold dry air from Mongolia into the region. During summer months, frontal cyclonic circulation develops when cold air masses from the north occlude cyclones from the southwest, generating precipitation. This circulation pattern brings maximum, albeit minor, precipitation to the Issyk-Kul region during the summer months and driest conditions during the winter months (Dando 1987; Aizen et al. 1995; Ricketts et al. 2001). The nearest climatic station at a comparable altitude to our site of investigation is located at Naryn $\left(41^{\circ} 43^{\prime} \mathrm{N}\right.$, $76^{\circ} 00^{\prime} \mathrm{E}, 2,039 \mathrm{~m}$ a.s.1.). Here the mean January and July temperatures are -15.8 and $17.3^{\circ} \mathrm{C}$ respectively, the mean annual temperature is $3.65^{\circ} \mathrm{C}$ and the mean annual precipitation $285.5 \mathrm{~mm}$ (World Climate 2006).

\section{Coring}

One short core (KA4) was taken with a Perspex-tube piston corer near the centre of the lake $\left(42^{\circ} 50^{\prime} 20^{\prime \prime} \mathrm{N}, 77^{\circ} 23^{\prime} 33^{\prime \prime} \mathrm{E}\right)$. For deeper sediment two parallel long cores (KA1 and KA2) were taken with a modified Streif-Livingstone piston corer (Merkt and Streif 1970). Water depth during all the coring was $3.18 \mathrm{~m}$. The cores were correlated by distinct sediment layers. KA1 was used as the main core, as it contained less gravel.

\section{Dating}

Accelerated mass spectrometry (AMS) ${ }^{14} \mathrm{C}$ ages were obtained from six terrestrial plant macrofossils from the sediments (Table 1) at the University of Poznan. The ${ }^{14} \mathrm{C}$ dates were converted to calibrated ages (year cal B.P.) with the program Calib version 5.0.1 (Stuiver and Reimer 1993). The depth-age model was based on linear interpolation of the median values of calibrated ${ }^{14} \mathrm{C}$ dates (Fig. 2).

Pollen and microscopic-charcoal analysis, and LOI

Pollen preparation followed standard procedures (Moore et al. 1991). Lycopodium tablets (Stockmarr 1971) were added to sub-samples of $1 \mathrm{~cm}^{3}$ for estimating pollen concentrations (grains $\mathrm{cm}^{-3}$ ) and accumulation rates (grains $\mathrm{cm}^{-2}$ year ${ }^{-1}$ ). Pollen types were identified with pollen keys (Moore et al. 1991; Beug 2004), pollen atlases (Reille 1992, 1998) and the reference collection of the Institute of Plant Sciences of the University of Bern. A minimum of 600 pollen grains, excluding aquatic pollen and spores, were counted at each level except at levels where pollen concentrations were extremely low. The identification of non-pollen objects in the pollen slides followed van Hoeve and Hendrikse (1998) and for spores of ascomycetes van Geel and Aptroot (2006). The pollen diagram was subdivided into local pollen assemblage zones (LPAZ) by the zonation method of optimal partitioning (Birks and Gordon 1985) as implemented in the program ZONE, version 1.2, written by Steve Juggins. To determine the number of statistically significant zones in diagrams, we used the program BSTICK.

Microscopic charcoal particles, i.e. black, completely opaque, and angular fragments (Clark 1988) longer than $10 \mu \mathrm{m}$ (or area $>75 \mu \mathrm{m}^{2}$ ), were counted in pollen slides following Tinner and $\mathrm{Hu}$ (2003) and Finsiger and Tinner 
Fig. 1 Map showing the location of the study site

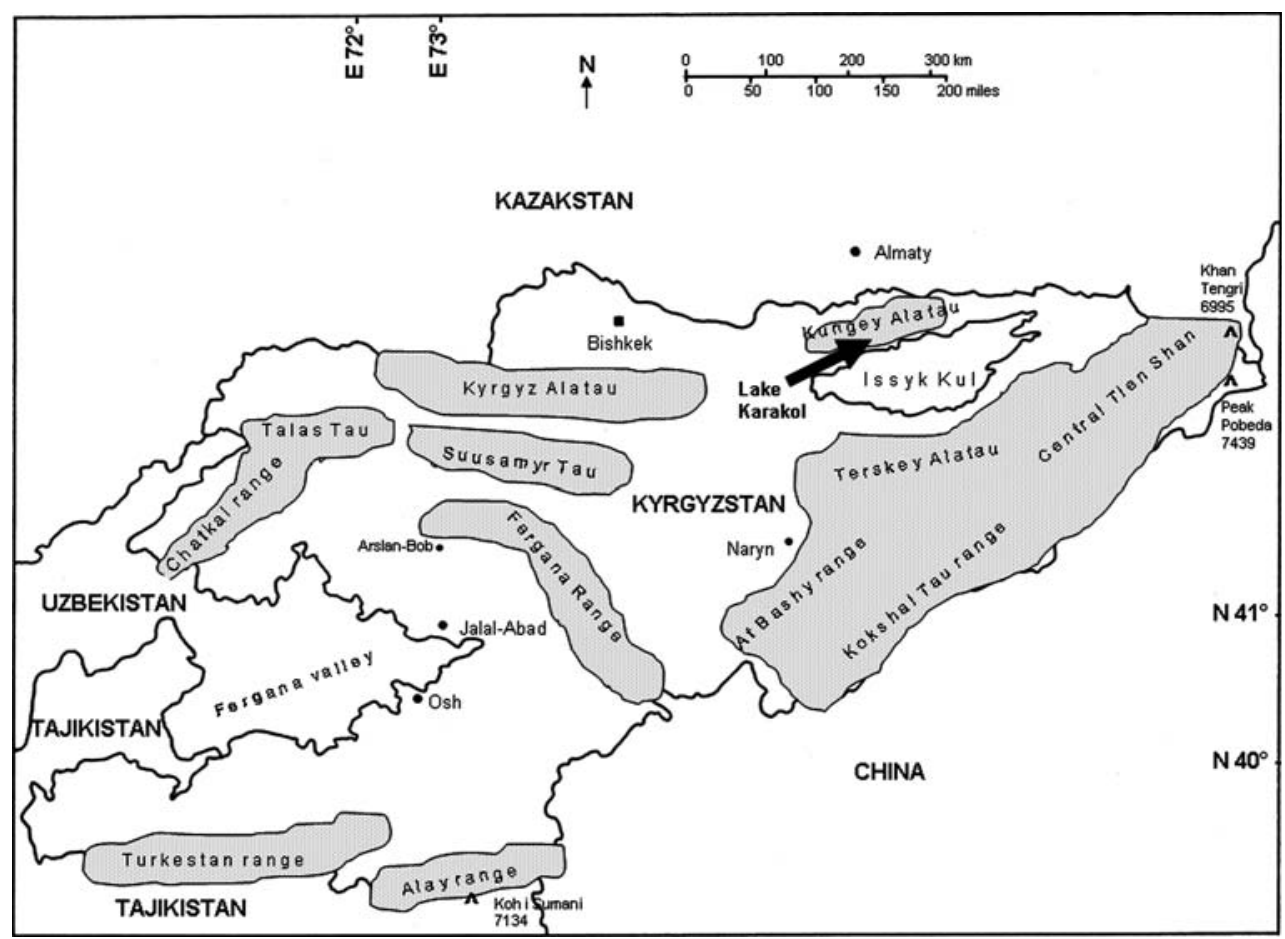

Table 1 Radiocarbon dates from Karakol, Kyrgyzstan

\begin{tabular}{lclccr}
\hline Lab. no. & Depth $(\mathrm{cm})$ & Material & ${ }^{14}$ C dates & Cal в.P. $(2 \sigma \text {-range })^{\text {a }}$ & Age in diagram $($ cal в.P. $)$ \\
\hline Poz-6477 & $51-53$ & 4 Bud fragments & $130 \pm 30$ & 275 to -3 & 128 \\
Poz-6478 & $79.5-87.5$ & Charcoal (needle) & $1,925 \pm 30$ & $1,947-1,817$ & 1,873 \\
Poz-6478 & $148-150$ & Wood & $3,110 \pm 35$ & $3,436-3,224$ & 3,340 \\
Poz-6479 & $226-228$ & Picea cone scale & $3,445 \pm 35$ & $3,831-3619$ & 3,709 \\
Poz-6481 & $273-275$ & Periderm, twigs & $3,550 \pm 35$ & $3,961-3720$ & 3,844 \\
Poz-6482 & $285.5-286.5$ & Picea needles & $3,600 \pm 35$ & $4,065-3784$ & 3,908 \\
\hline
\end{tabular}

${ }^{a}$ Calibration of radiocarbon dates: Calib 5.0.1 (Stuiver and Reimer 1993)

(2005). Charcoal concentration (particles $\mathrm{cm}^{-3}$ ) and influx (particles $\mathrm{cm}^{-2}$ year ${ }^{-1}$ ) were estimated by using the same approach as for pollen (Stockmarr 1971). Charcoal area influx was estimated from the regression proposed for Lago di Origlio (Southern Switzerland) by Tinner and Hu (2003)

LOI analyses to estimate the organic matter and carbonate content of the sediment were carried out on $1 \mathrm{~cm}^{3}$ samples at the same depths as for pollen analysis following the recommendations of Heiri et al. (2001)

\section{Results and interpretation}

Chronology, lithology, and LOI

The chronology is based on six radiocarbon dates from terrestrial plant material (Table 1). All dates were accepted for the depth-age model (Fig. 2a). The sediments of Karakol show rather marked changes between gyttja, silt, sand and gravel (Fig. 2b; Table 2). However, only fine material (gyttja and silt) was sub-sampled for pollen and charcoal analyses. Organic matter (Fig. 2c) as indicated by LOI at $550^{\circ} \mathrm{C}$ is high $(60 \%)$ near the bottom of the sequence $(276 \mathrm{~cm}, 3,870 \mathrm{cal}$ year B.P.) but in correspondence with sandy and silty layers drops to values around $10 \%$ at $271-182 \mathrm{~cm}(3,850-3,500 \mathrm{cal}$ year в.P.). Subsequently (182-112 cm, 3,500-2,500 cal year в.P.), organic content is very low with a small peak at $153 \mathrm{~cm}$ in a gyttja layer (3,350 cal year в.P.). The organic content reaches values around $10 \%$ at $112-80 \mathrm{~cm}(2,500-1,700 \mathrm{cal}$ year B.P.) and increases to $80 \%$ at $80-50 \mathrm{~cm}(1,700-170 \mathrm{cal}$ year B.P.), in correspondence with the peat horizon. Towards the top of the sequence, the organic content drops to values around $15 \%$ at $50-3.5 \mathrm{~cm}(170-0 \mathrm{cal}$ year в.P.) coinciding 
Fig. 2 a Depth-age model of Karakol. b Lithology of the sediment of Karakol and losson-ignition results after combustion of $1 \mathrm{~cm}^{3}$ sediment at 550 and $950^{\circ} \mathrm{C}$. Variations in LOI represent changes in organic matter content and carbonate content at these temperatures, respectively
A

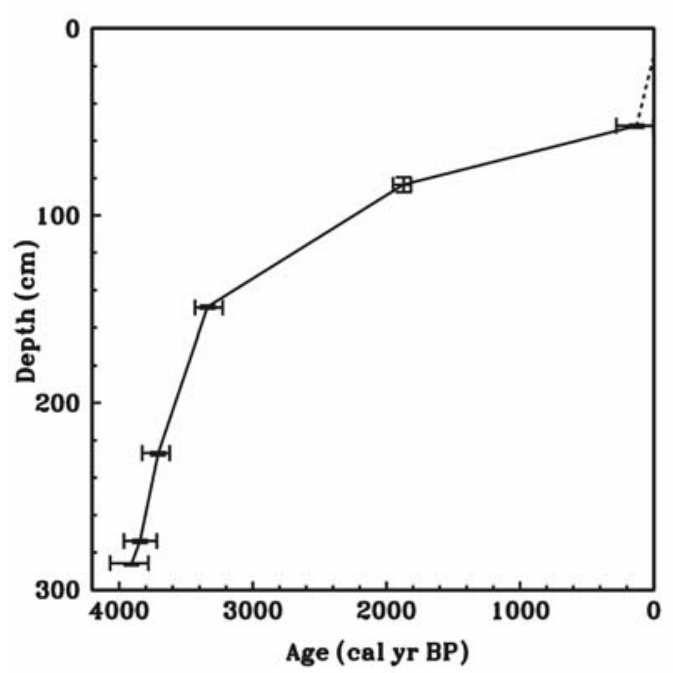

B

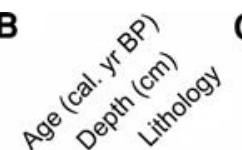

C

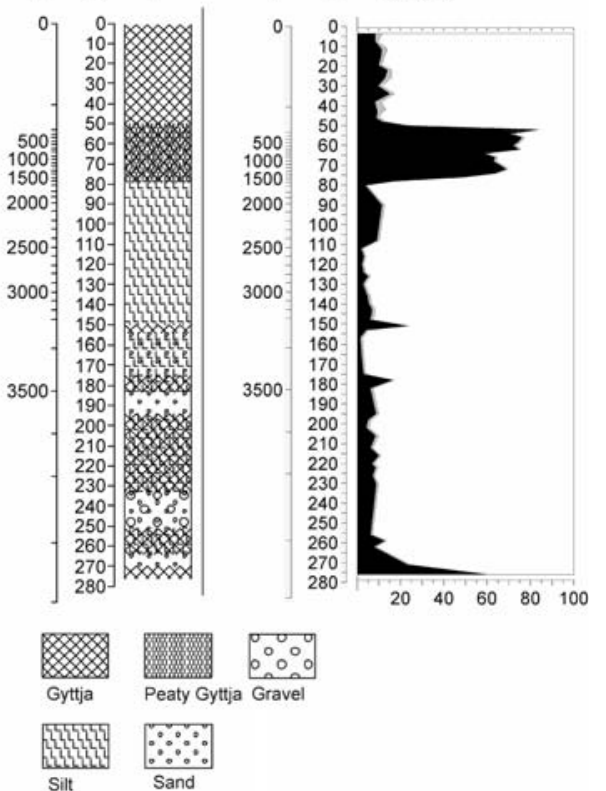

Table 2 Lithographical layers of the sediment at Karakol

\begin{tabular}{ll}
\hline Depth $(\mathrm{cm})$ & Sediment \\
\hline $0-50$ & Gyttja \\
$50-79$ & Peaty gyttja \\
$79-150$ & Silt and sand \\
$150-154$ & Gyttja \\
$154-175$ & Silt and sand \\
$175-183$ & Silty gyttja \\
$183-194$ & Sand \\
$194-233$ & Silty gyttja \\
$233-251$ & Sand and gravel \\
$251-270$ & Sand \\
$270-276$ & Gyttja \\
\hline
\end{tabular}

with the sediment change from peat to gyttja. Carbonate content as indicated by LOI at $950^{\circ} \mathrm{C}$ is remarkably low throughout the stratigraphy.

Pollen and charcoal

A total of 73 pollen samples were analysed. Pollen percentage, concentration and influx values are comparable, and we therefore use the percentage (Fig. 3, left) and influx (Fig. 3, right) results for further discussion. The charcoal stratigraphy is discussed together with the pollen within the eight zones that have proven to be statistically significant.
KA-1: 276-274 cm; 3,870-3,850 cal year B.P.: closed s ub-alpine forests of $P$. schrenkiana

High percentage values (up to 40\%) of arboreal pollen dominated by Picea characterize this oldest zone. Many Picea stomata and several $P$. schrenkiana needles were found in the sediment at the base of the core. Pollen of Betula-type, Alnus incana-type, and Fraxinus sogdiana are present in only very low percentages. The pollen of herbaceous taxa accounts for $60-70 \%$ of the pollen sum and is mainly represented by steppe elements (e.g. Artemisia, Chenopodiaceae and Poaceae). A minor peak in Cichorioideae reaches $5 \%$.

Pollen data suggest the presence of rather closed forests of $P$. schrenkiana around the lake during this period. Picea was admixed with some Betula, Alnus and Fraxinus trees. Steppes and meadow vegetation were probably restricted to the drier lowlands.

KA-2: 274-214 cm; 3,850-3,640 cal year B.P.: opening of $P$. schrenkiana forest, expansion of meadow and steppe vegetation

At the onset of this zone pollen and stomata from Picea decline. After a minimum at a depth of $260 \mathrm{~cm}$ (ca. 3,800

Fig. 3 Pollen percentage and microscopic charcoal diagram (left) and pollen influx diagram (right) from Karakol; unfilled curves show $\times 10$ exaggerations 


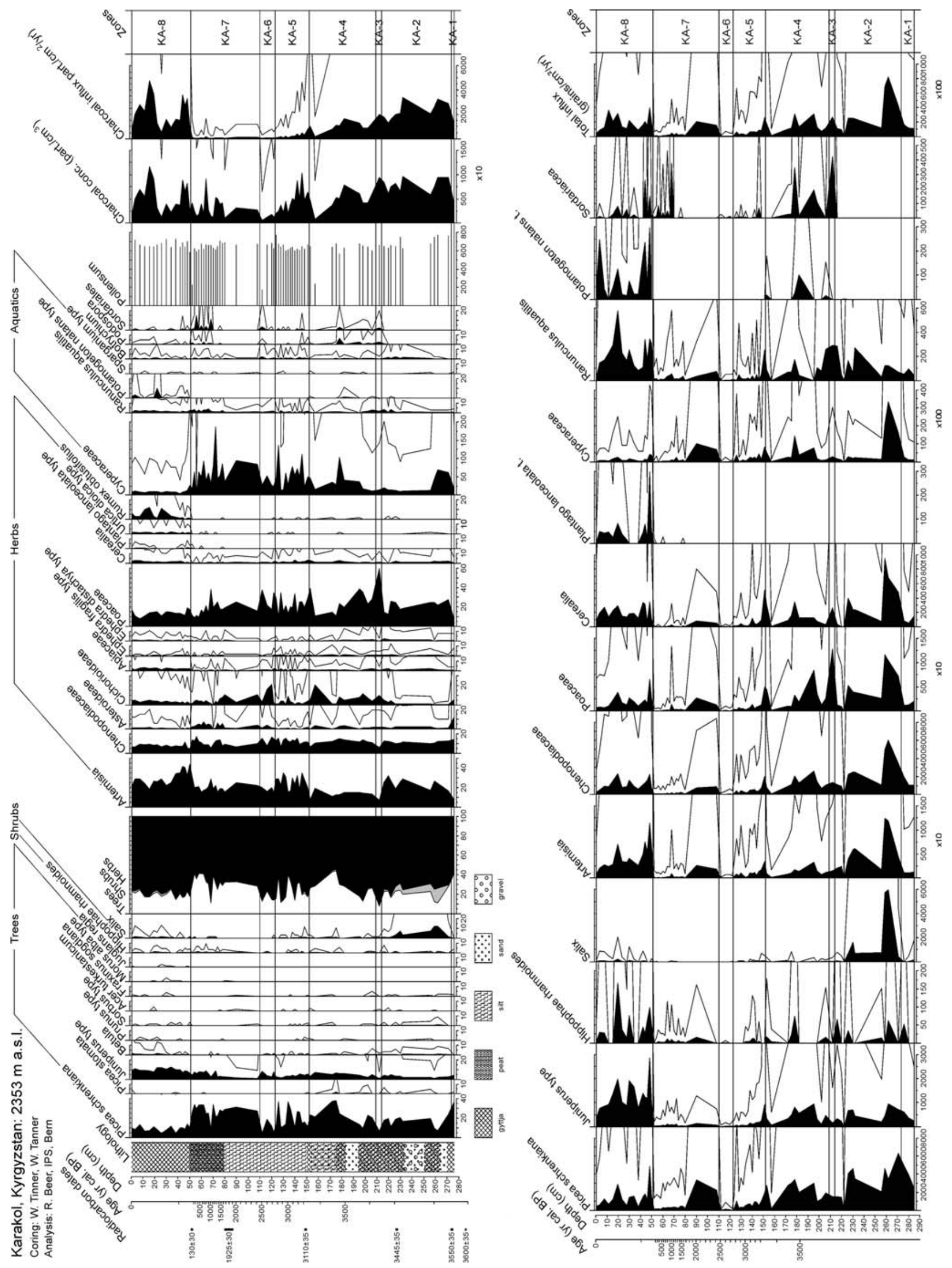


cal year в.Р.) the values increase to $20 \%$. A marked rise in the pollen of Salix begins at $274 \mathrm{~cm}$ (ca. 3,850 cal year в.P.). Salix pollen subsequently increases and reaches a maximum of $12 \%$ at $260 \mathrm{~cm}$ (ca. 3,800 cal year в.P.), when different pollen types of Rosaceae show minor peaks as well. After this maximum Salix pollen shows a declining trend throughout the rest of KA-2. The increase in Salix pollen is accompanied by a rise in Artemisia (30\%) and Poaceae (25\%). Chenopodiaceae pollen remains stable at $10 \%$, and that of Cyperaceae shows one, very marked peak, at $260 \mathrm{~cm}$. Ranunculus aquatilis pollen has distinct peaks at 224 and $216 \mathrm{~cm}$. Botrychium spores show an increasing trend from $268 \mathrm{~cm}$ onwards and reach comparatively high values at $224 \mathrm{~cm}$ (3,700 cal year B.P.). Rather high charcoal concentrations and accumulation rates occur throughout this pollen zone. Influx values of around 3,000 and 2,000 particles $\mathrm{cm}^{-2}$ year $^{-1} \quad\left(1.08-0.74 \mathrm{~mm}^{-2} \mathrm{~cm} \quad\right.$ year $\left.^{-1}\right)$ occur. The core sediments are characterized by the conspicuous presence of sand and gravel between 250 and $232 \mathrm{~cm}$.

According to the pollen record the spruce forests first opened around 3,800 cal year B.P., possibly induced by climatic or environmental changes. Natural forest fires probably played an important role in the ecology of the forests. The expansion of Salix and enhanced presence of different types of Rosaceae as well as Cyperaceae pollen possibly reflect a larger belt of pioneer and shore vegetation around the lake as a response to the opening of the forests. Increased erosional input (sand and gravel layer) may have directly resulted from forest openings. Ranunculus aquatilis was probably growing in shallow and possibly eutrophic water with a low calcareous content.

KA-3: 214-209 cm; 3,640-3,615 cal year B.P.: grassland and open P. schrenkiana forests

This zone shows a marked peak in Poaceae pollen of $60 \%$ and a peak in Cichorioideae of 10\%. Spores of Podospora and other Sordariales are present. A peak in charcoal at $211 \mathrm{~cm}$ (ca. 2,630 cal year B.P.) reaching an accumulation rate of 2,000 part. $\mathrm{cm}^{-2}$ year $^{-1}\left(0.74 \mathrm{~mm}^{2} \mathrm{~cm}^{-2}\right.$ year $\left.^{-1}\right)$ coincides with a decline in all arboreal and shrub taxa and is accompanied by a minimum for Artemisia and Chenopodiaceae.

The pollen record suggests a forest opening possibly caused by fire, for charcoal reaches a rather high influx of 2,000 part. $\mathrm{cm}^{-2}$ year ${ }^{-1}\left(0.74 \mathrm{~mm}^{2} \mathrm{~cm}^{-2}\right.$ per year $)$ It is possible that parts of the steppe vegetation burnt as well, allowing grasslands to become dominant during this time period of 25 years.
KA-4: 209-152 cm; 3,615-3,350 cal year B.P.: meadows and steppe vegetation and woods of $P$. schrenkiana

The arboreal pollen shows a positive trend due mainly to the increase in Picea pollen, which reaches $25 \%$ at the top of the zone. Poaceae pollen decreases, while Chenopodiaceae and Cichorioideae show rather constant values of about 12 and $8 \%$. Artemisia pollen reaches minimum values throughout the zone (15\%). Podospora and other spores of the Sordariales show high values throughout this zone and a peak at $180 \mathrm{~cm}(3,450 \mathrm{cal}$ year B.P.). Finally, a peak in charcoal $\left(1,500\right.$ part. $\mathrm{cm}^{-2}$ year ${ }^{-1}, 0.56 \mathrm{~mm}^{2} \mathrm{~cm}^{-2}$ per year), which has no corresponding pollen change, occurs at $184 \mathrm{~cm}(3,500 \mathrm{cal}$ year B.P.).

Our pollen data suggest that forest expanded during the 250 years of this zone. Meadow plants included Cichorioideae and Poaceae. The increase in fire frequency around 3,500 year cal в.P. could have originated from patches of vegetation burning beyond the pollen catchments, so that any vegetational responses were not recorded in our pollen data.

KA-5: 152-124 cm, 3,350-2,800 cal year B.P.:

$P$. schrenkiana forests and steppe vegetation

The pollen of Picea shows a series of sharp stepwise declines at 152, 140, and $128 \mathrm{~cm}(3,350,3,150$, and 2,900 cal year в.P.). After $146 \mathrm{~cm}$ (3,200 cal year в.Р.) no Picea stomata are found till the end of KA1-7. The series of declines in Picea pollen corresponds to peaks of Artemisia and Chenopodiaceae reaching 25 and $15 \%$. Salix pollen is represented at low but constant values, while Botrychiumtype spores show high values from $150 \mathrm{~cm}$ onwards. All pollen curves show quickly changing values, whereas pollen accumulation rates show a steep stepwise decrease during this zone. Charcoal influx is rather low and shows a declining trend in this zone $\left(1,000\right.$ part. $\mathrm{cm}^{-2}$ year ${ }^{-1}$, $0.39 \mathrm{~mm}^{2} \mathrm{~cm}^{-2}$ per year).

The series of Picea pollen declines probably reflects marked diebacks of Picea forests. Steppe vegetation and meadows possibly expanded on open patches where Picea collapsed. The lack of plants indicative of human impact (e.g. Plantago lanceolata-type) points to climatic or environmental changes as primary driving factors. Interestingly, fires (as inferred from charcoal influx) seemed to play a less significant role, although more fuel (dead biomass from the dieback of the forests) was present locally.

KA-6: $124-110 \mathrm{~cm}, 2,800-2,500$ cal year B.P.:

$P$. schrenkiana and steppe vegetation

Marked declines in Picea are recorded at 122 and $112 \mathrm{~cm}$ (2,800 and 2,520 cal year B.P.). Small but distinctive peaks 
of Juniperus-type pollen occur at the same levels, and a peak in Cichoroideae is recorded at about 2,800 cal B.P. $(120 \mathrm{~cm})$. Accumulation rates of all pollen types reach minimal values towards the younger zone border of KA-6. Charcoal influx shows lowest values during this zone (100 part. $\mathrm{cm}^{-2}$ year ${ }^{-1}, 0.04 \mathrm{~mm}^{2} \mathrm{~cm}^{-2}$ per year)

The series of declines in Picea continues and reaches its culmination at the end of KA6, probably reflecting further marked diebacks of Picea stands which peaked at 2,8002,600 cal year B.P. Forest fires seemed to have played a minor role during this time period.

\section{KA-7: 110-51 cm, 2,500-190 cal year B.P.: closed forests} of $P$. schrenkiana

This long-lasting zone is characterized by high percentages of Picea pollen, though only a single Picea stomate was found at $62 \mathrm{~cm}$. Picea pollen decreases briefly at $76 \mathrm{~cm}$ (1,300 cal year B.P.) and $68 \mathrm{~cm}$ (1,100 cal year B.P.). However, Artemisia and Chenopodiaceae pollen shows rather constant values of 20 and $10 \%$, and Poaceae pollen decreases from 20 to $10 \%$. A first small peak in $P$. lanceolata-type pollen is found at $78 \mathrm{~cm}$, only briefly before Picea pollen decreases for the first time in this zone. From $70 \mathrm{~cm}$ onwards Sordariales spores occur again together with higher frequencies of Botrychium-type spores. Very low accumulation rates of charcoal (100 part. $\mathrm{cm}^{-2}$ year ${ }^{-1}, 0.04 \mathrm{~mm}^{2} \mathrm{~cm}^{-2}$ per year) are found in this zone. Between 114 and $80 \mathrm{~cm}$, the accumulation rates of all pollen types reach maximal values followed by a marked decline around $80 \mathrm{~cm}$.

The pollen record suggests an expansion of Picea, which was able to form rather dense forests around the lake between 2,500 and 190 cal year B.P. We assume that this period is representative of fairly natural vegetation under the environmental conditions of that time. The occurrence of Plantago lanceolata-type coincided with the appearance of dung spores as well as an expansion of Botrychium. It is likely that at least some of the transient changes around 1,000 cal year B.P. were induced by moderate human impact in the region. Interestingly, fires seemed to have played a minor role throughout the 2,310 years covered by this zone.

KA-8: 51-0.5 cm 190 cal year B.P. to present: meadow and steppe vegetation and woods of $P$. schrenkiana

Picea schrenkiana pollen declines sharply from 35 to $10 \%$ at the beginning of this zone. Other arboreal pollen such as Betula-type and Morus alba-type occurs with slightly higher values than before. From $36 \mathrm{~cm}$ (ca. 100 cal year
B.P.) onwards, single pollen grains of Juglans regia are recorded. Juniperus-type pollen shows an increasing trend and reaches $12 \%$ at $20 \mathrm{~cm}$. A sharp increase in pollen of Artemisia coincides with a decrease in Picea. Conspicuous values of Plantago lanceolata-type and Urtica occur at 51$42 \mathrm{~cm}$ (200-100 cal year B.P.). Spores of dung fungi are found throughout the zone. A remarkable peak in Rumex obtusifolius-type pollen occurs at $26 \mathrm{~cm}$ (60 cal year B.P.). High concentration and influx values of charcoal are found in this zone (e.g. up to 4,000 part. $\mathrm{cm}^{-2}$ year $^{-1}$, $1.41 \mathrm{~mm}^{2} \mathrm{~cm}^{-2}$ per year $\left.{ }^{-1}\right)$. Pollen of the wetland plants Cyperaceae and $R$. aquatilis decreases markedly at the beginning of the zone, while the pollen of other water plants (e.g. Myriophyllum-type, Potamogeton natans-type) increases.

During this period a strong shift in the vegetation composition occurred. As the collapse of Picea forests coincided with the appearance of human indicators (e.g. P. lanceolata-type, Urtica, Rumex obtusifolius-type), it is likely that human impact contributed to the disruption of spruce forests ca. 200 years ago. Our data (i.e. sedimentary change, Cyperaceae pollen, and pollen of aquatic plants) point to a rise in lake-level during the past 200 years.

\section{Discussion}

The pollen and charcoal record reaches back to 4,000 cal year B.P. and documents important vegetation and firehistory changes during the late Holocene. Older sediments could not be recovered as an impenetrable rocky layer was reached at the depth of $280 \mathrm{~cm}$. Picea schrenkiana was the dominant tree species in the forests over the entire period as implied by pollen, stomata and macrofossils (needles) found at the base of the record. As suggested by the relatively high percentages of spruce pollen (Beer et al. 2007a, b), the trees most probably formed rather closed stands around the lake at the beginning of our record. An interesting question arises as to where the endemic tree survived the last glaciation. Unfortunately it cannot be addressed thoroughly by our pollen record, as this does not go back far enough. However, our record unambiguously documents the natural presence of the tree since the beginning of the sediment record. The glaciers on the mountain ranges surrounding Lake Issyk-Kul extended almost to the present lake shore during the last glaciation (Grosswald et al. 1994). Given the fact that the present range of $P$. schrenkiana is confined to the western part of the Tien Shan (Farjon 1990), it is most likely that the refugia were confined to our region, and that the tree survived locally in ice-free and sheltered spots in the lowlands of the Tien Shan mountain system. This interpretation is supported by the new Bakaly (Sary Chelek region) pollen record, which 
documents a presence of Picea back to 6,800 year cal B.P. which is where this record ends (Beer et al. 2008).

\section{Climate and vegetation dynamics}

Ricketts et al. (2001) have recently reconstructed climatic changes implied by changes in trace elements and in stableisotope composition of ostracods from Lake Issyk-Kul. A major transition from relatively humid to more arid conditions occurred between 6,900 and 4,900 cal B.P. For the remainder of the record relatively stable conditions analoguous to the modern situation are inferred. A recent highresolution multidisciplinary study covering the past 1,000 years documents increased humidity at A.D. 10001100 and 1700-1900 (Giralt et al. 2004). A progressive trend to more aridity is indicated for many parts of West and Central China (An et al. 2000) and for Pakistan (von Rad et al. 1999) from ca. 4,000 cal year B.P. onwards. Relatively high temperatures are reported from 6,000 to 4,500 cal year B.P. for Central Asia (Christian 1998). A sharp decrease in temperatures to rather low values occurred between 4,500 and 4,050 cal year B.P., reverting to higher values again between 4,050 and 3,100 cal year B.P. Stable temperatures comparable to modern values are reported from 3,100 cal year B.P. up to the present.

Our new high-mountain record documents changing frequencies of $P$. schrenkiana pollen and conspicuous sediment changes (i.e. layers of silt, sand, and gravel, suggesting high erosional input into the lake) throughout the past 4,000 years. The series of Picea declines around 3,800 cal year B.P. and between 3,300 and 2,500 cal year B.P., with a culmination at 2,800-2,600 cal B.P., may point to climatic or environmental shifts (e.g. change in precipitation or cooling). Since the declines in Picea are accompanied by increases in Artemisia, cooling rather than aridity might have been important (El-Moslimany 1990). This interpretation is supported by the large increase in Cichorioideae, abundant in (sub) alpine meadows, at 2,800-2,600 cal year B.P. However, at our site Picea is far below its uppermost altitudinal limit, thus temperature drops alone would probably not have been sufficient to generate these very strong forest declines around the site. In fact, Artemisia and some Cichorioideae (e.g. Saussurea) also occur under arid high-montane conditions in $\mathrm{Ky}-$ rgyzstan (P. Pokorný, personal communication). Taken together, our data suggest that combined effects of temperature cooling and precipitation declines triggered substantial Picea forests diebacks in the Karakol area. Global cooling around 2,800 cal B.P. (850 B.c.) has been suggested by many authors (e.g. Denton and Kàrlen 1973; van Geel et al. 1996, 1999; Bond et al. 1997; 2001). The cooling event was probably induced by a decrease in solar activity as reflected in the ${ }^{14} \mathrm{C}$-residual curve (Stuiver and Braziunas 1991). Another similar episode is reported around 2,400 cal B.P. (450 B.C.; Bond et al. 1997, 2001). At Lake Bakaly, a site located in the mixed forests of the Sary Chelek region in the Chatkal Range (Kyrgyzstan), a conspicuous expansion of Juniperus started at 2,800 cal B.P. and was followed by the expansion of Abies (with pollen absent prior to 2,500 cal B.P., Beer et al. 2008). In the Sary Chelek region, Abies may have benefited from increased moisture availability as a result of lower temperatures. Our new evidence of climatic change at around 2,800-2,600 cal year B.P. is in contrast with the reported stable climatic conditions reconstructed for Central Asia during the late Holocene. However, the question remains unresolved until further investigations are carried out in this region, especially at high-altitude sites, which are particularly sensitive to climatic changes (e.g. Tinner and Theurillat 2003).

Vegetation history and human impact

Prehistoric traces of Neolithic human activities ascribed to the Hissar cultures, whose remains have been found along the mountain rim from the Amu Darya to Lake Issyk-Kul (ca. $30 \mathrm{~km}$ down slope from our site) are dated from the seventh to the fifth millennium B.c. (Christian 1998). Most sites appear to have been seasonal camps of hunters following hoofed animals. Until the second half of the fourth millennium, southern Central Asia remained firmly within the village world of the early Neolithic. Objects from a destroyed Saka kurgan on the shore of Lake Issyk-Kul date back to the eighth to sixth century B.C., and many sites dating to the Saka period from the fifth and third centuries B.c. have been discovered in the valleys surrounding the Fergana valley (Yablonsky 1995). We would therefore expect that early human impact could be visible in the pollen diagram at least from 2,800 cal year B.P. The sharp stepwise declines of Picea schrenkiana between 3,300 and 2,500 cal year B.P. point to forest openings (Fig. 3, left). Yet, since a clear indicator of human impact, Plantago lanceolata-type (Beer et al. 2007a, b) is missing from our pollen record at this point, we prefer to relate the die-back of the forest to climatic deteriorations that occurred during this time period. The earliest finds of $P$. lanceolata-type pollen are recorded around 1,600 cal year B.P. We therefore assume that tribes of steppe nomads lived in the lowlands of Lake Issyk-Kul, but that their impact on the high-altitudinal spruce forests was marginal. It is conceivable that the steppe-forest ecosystem of the western Tien Shan was adapted to grazing by wild (e.g. wild sheep, ibex) and domesticated animals and that an interrelation between the animals and the plant cover formed a dynamic equilibrium (Gottschling 2006). The regular finds of the spores of 
ascomycetes growing on dung (Podospora, Sordariales; van Geel and Aptroot 2006) throughout the sedimentary record probably point to a constant level of grazing in the region, but it is difficult to assess whether this was natural or pastoral grazing.

A sharp decline in Picea schrenkiana is recorded in the uppermost zone (KA-8: 190 cal year B.P. to present, Fig. 3, left). In this case, the abundance of plants indicative of human activities (e.g. Plantago lanceolata-type and Urtica dioica-type pollen) clearly points to human impact as the main trigger (Fig. 3, left). In agreement with this, several historical events are reported for this time period that could have caused the strong die-back of the forests recorded in the pollen record. By the 1820s the influence of the Kokand khanate (Uzbek tribe) began to extend into the Tien Shan. To enforce its power and protect the caravan routes from China to the Caucasus and Russia, the Kokand people built a string of fortresses, one of which was Pishpek, located in the modern Bishkek (Stewart 2002). The disruption of Picea forests may thus be related to logging of trees for construction or intensification of agriculture as related to a certain economic wealth. In 1860s the Russians launched an attack on the Bishkek fortress. It took seven days and several tons of gunpowder to destroy the structure. Extraordinarily the Russians then returned to their military base at Verniy (Almaty), and the Kokand khanate rebuilt the fort (Stewart 2002). The Kokand khanate came to an end in the year 1877. From this time on the Russians were involved in the history of today's Kyrgyzstan (Stewart 2002), and their influence may have led to an intensification of agriculture and to some extent industrialisation. In fact the forests did not recover from the openings that had occurred at around 1,800 A.D.

More recently, it is reported that during the Second World War great areas of the spruce forests were logged for fuel supply (Gottschling 2006). After the end of the war the remaining forests were protected enabling them to recover to a certain degree. Although logging of the trees was forbidden, open patches of the forests were heavily grazed and therefore natural regeneration was limited. Maximal numbers of grazing animals were achieved in the late 1980s, when the number of sheep alone increased fivefold (from 360,000 in 1989 to 1.9 million in 1991) in the Issyk-Kul region. Degradation of pastures and a lack of forest regeneration became an issue of concern (Gottschling 2006). It is supposed that the potential natural forest area would double under natural conditions (Gan 1982). Our palaeoecological record supports this assumption, considering the close connection between the decline of Picea forests, the expansion of weeds such as Plantago lanceolata and Urtica dioica 190 years ago, and the onset of historically reported intensive human activities in this region. The conspicuous increases of charcoal concentration and accumulation rates at the same time imply that forest fires became more important and were possibly induced anthropogenically.

Taken together our results suggest that Picea forests in this area are natural and have a millennial history. It is probable that under undisturbed conditions they would expand and invade meadows that were created for agricultural purposes only ca. 200 years ago.

Acknowledgments We thank Ennio Grisa, Gabriele Carraro, Willi Tanner, Zakir Sarymsakov, Bronislav I. Venglovsky and all Kyrgyz friends who assisted in the extensive field trip in 2003. The steady support of this project by Brigitta Ammann is gratefully acknowledged. Comments by H.E. Wright Jr. were helpful in improving the manuscript. We are grateful to André F. Lotter, Keith Bennett and Petr Pokorný for their helpful comments and suggestions to improve the manuscript. We are also very grateful to Intercooperation Bern and Bishkek, Project KIRFOR (Kyrgyz-Swiss Forestry Support Programme) and to the University of Bern for financially supporting this study.

\section{References}

Aizen VB, Aizen EM, Melack JM (1995) Climate, snow cover, glaciers, and runoff in the Tien Shan, Central Asia. Water Resour Bull 31:1113-1127

An Z, Porter SC, Kutzbach JE, Xihao W, Suming W, Xiaodong L, Xiaoqiang L, Weijian Z (2000) Asynchronous Holocene optimum of the East Asian monsoon. Q Sci Rev 19:743-762

Beer R, Tinner W, Grisa E, Carraro G (2007a) Pollen representation in surface samples of the Juniperus, Picea and Juglans forest belts of Kyrgyzstan, Central Asia. Holocene 17:599-611

Beer R, Heiri O, Tinner W (2007b) Vegetation history, fire history and lake development recorded for 6300 years by pollen, charcoal, loss on ignition, and chironomids at a small lake in southern Kyrgyzstan (Alay Range, Central Asia). Holocene 17:979-987

Beer R, Kaiser F, Schmidt K, Ammann B, Carraro G, Grisa E, Tinner W (2008) Vegetation history of the walnut forests in Kyrgyzstan (Central Asia): natural or anthropogenic origin? Q Sci Rev (in press)

Beug H-J (2004) Leitfaden der Pollenbestimmung für Mitteleuropa und angrenzende Gebiete. Pfeil, München

Birks HJB, Gordon AD (1985) Numerical methods in quaternary pollen analysis. Academic Press, London

Böhner J (1996) Säkulare Klimaschwankungen und rezente Klimatrends Zentral- und Hochasiens. Göttinger Geographische Abhandlungen 101

Bond G, Showers W, Cheseby M, Almasi P, deMenocal P, Priore P, Cullen H, Hajdas I, Bonani G (1997) A pervasive millennialscale cycle in North Atlantic Holocene and Glacial climates. Science 278:1257-1266

Bond G, Kromer B, Beer J, Muscheler R, Evans MN, Showers W, Hoffmann S, Lotti-Bond R, Hajdas I, Bonani G (2001) Persistent solar influence on North Atlantic climate during the Holocene. Science 294:2130-2136

Christian D (1998) A history of Russia, Central Asia and Mongolia, vol 1. Inner Eurasia form Prehistory to the Mongol Empire. Blackwell, Oxford

Clark JS (1988) Stratigraphic charcoal analysis on petrographic thin sections: application to fire history in Northwestern Minnesota. Quatern Res 30:81-91 
Dando WA (1987) Climate of Asia. In: Oliver JE, Fairbridge RW (eds) The encyclopedia of climatology. Van Nostrand Reinhold Company, New York, pp 116-126

Denton GH, Karlèn W (1973) Holocene climatic variations-their pattern and possible cause. Quatern Res 3:155-205

El-Moslimany AP (1990) Ecological significance of common nonarboreal pollen: examples from drylands of the Middle East. Rev Palaeobot Palynol 4:343-350

Esper J (2000) Paläoklimatische Untersuchungen an Jahrringen im Karakorum und Thien Shan Gebirge (Zentralasien). Bonner Geographische Abhandlungen 103

Farjon A (1990) Pinaceae: drawings and descriptions of the genera Abies, Cedrus, Pseudolarix, Keteleeria, Nothotsuga, Tsuga, Cathaya, Pseudotsuga, Larix, and Picea. Koeltz, Königstein, pp 246-247

Finsiger W, Tinner W (2005) Minimum count sums for charcoalconcentration estimates in pollen slides: accuracy and potential errors. Holocene 15:292-297

Gan PA (1982) Lesnoy fond Kirgizii za poslednie 50 let I ego sovremennoe sostoyanie (The forests of Kyrgyzstan in the past 50 years and their condition). In: problemy osvoeniya gor (Problems of the development of mountain area). Izvestiya Akademii Nauk Kirg. Frunze, SSR

Giralt S, Julià R, Klerkx J, Riera S, Leroy S, Buchaca T, Catalan J, De Batist M, Beck C, Bobrov V, Gavshin V, Kalugin I, Sukhorukov F, Brennwald M, Kipfer R, Peeters F, Lombardi S, Matychenkov V, Romanovsky V, Podsetchine V, Voltattorni N (2004) 1,000 year environmental history of Lake Issyk-Kul. In: Nihoul J, Zavialov P, Micklin P (eds) Dying and Dead Seas, climatic versus anthropic causes. NATO ASI Series, vol 36. Kluwer, Dordrecht, pp 253-285

Gottschling H (2006) Die Naturräume des Biosphärenreservates Issyk-Kul in Kirgisistan. Greifswalder Geographische Arbeiten 36:245

Gottschling H, Amatov I, Lazkov G (2005) Zur Ökologie und Flora der Walnuss-Wildobst-Wälder in Süd-Kirgisistan. Archiv für Naturschutz und Landschaftsforschung 44:85-130

Grosswald MG, Kuhle M, Fastook JL (1994) Würm Glaciation of Lake Issyk-Kul area, Tien Shan Mts: a case study in glacial history of Central Asia. Geol J 33:273-310

Heiri O, Lotter AF, Lemcke G (2001) Loss on ignition as a method for estimating organic and carbonate content in sediments: reproducibility and comparability of results. J Paleolimnol 25:101-110

Merkt J, Streif HJ (1970) Stechrohrbohrgerät für limnische und marine Lockersedimente. Geologisches Jahrbuch 88:137-148

Miehe S, Cramer T, Jacobsen JP, Winiger M (1996) Humidity conditions in the western Karakorum as indicated by climatic data and corresponding distribution patterns of the montane and alpine vegetation. Erdkunde 50:190-204

Moore PD, Webb JA, Collinson ME (1991) Pollen analysis. Blackwell, Oxford
Musuraliev TM (1998) Forest management and policy for the walnutfruit forests of the Kyrgyz Republic. In: Blaser J, Carter J, Gilmour D (eds) Biodiversity and sustainable use of Kyrgyzstan's walnut-fruit forests. English version. IUCN, Intercooperation, Gland, Cambridge, pp 3-17

Reille M (1992) Pollen et spores d'Europe et d'Afrique du Nord. Laboratoire de Botanique Historique et Palynologie, Marseille

Reille M (1998) Pollen et spores d'Europe et d'Afrique du Nord. Supplément 2. Laboratoire de Botanique Historique et Palynologie, Marseille

Ricketts RD, Johnson TC, Brown ET, Rasmussen KA, Romanovsky VV (2001) The Holocene paleolimnology of Lake Issyk-Kul, Kyrgyzstan: trace element and stable isotope composition of ostracodes. Palaeogeogr Palaeoclimatol Palaeoecol 176:207-227

Stewart R (2002) Kyrgyzstan. Odyssey Publications, Hong Kong

Stockmarr J (1971) Tablets with spores used in absolute pollenanalysis. Pollen et spores 13:615-621

Stuiver M, Braziunas TF (1991) Climatic, solar, oceanic and geomagnetic influences on Late-Glacial and Holocene atmospheric ${ }^{14} \mathrm{C} /{ }^{12} \mathrm{C}$ change. Quatern Res 35:1-24

Stuiver M, Reimer PJ (1993) Extended ${ }^{14} \mathrm{C}$ data base and revised CALIB 3.0 14C age calibration program. Radiocarbon 35:215230

Tinner W, Hu FS (2003) Size parameters, size-class distribution and area-number relationship of microscopic charcoal: relevance for fire reconstruction. Holocene 13:499-505

Tinner W, Theurillat JP (2003) Uppermost limit, extent, and fluctuation of the timperline and treeline ecocline in the Swiss Central Alps during the past 11,500 years. Arctic Antarct Alpine Res 35:158-169

Van Geel B, Aptroot A (2006) Fossil ascomycetes in Quaternary deposits. Nova Hedwigia 82:313-329

Van Geel B, Buurman J, Waterbolk HT (1996) Archeological and palaeoecological indications of an abrupt climatic change in The Netherlands, and evidence for climatological teleconnections around 2650 B.P. J Quat Sci 11:451-460

Van Geel B, Raspopov OM, Renssen H, van der Plicht J, Dergachev VA, Meijer HAJ (1999) The role of solar forcing upon climate change. Q Sci Rev 18:331-338

Van Hoeve ML, Hendrikse M (eds) (1998) A study of non-pollen objects in pollen slides (the types as described by van Geel and colleagues). Unpublished report, University of Amsterdam

Von Rad U, Schaaf M, Michels KH, Schulz H, Berger WH, Sirocko F (1999) A 5000-yr record of climate change in varved sediments from the oxygen minimum zone of Pakistan, Northeastern Arabian Sea. Quatern Res 51:39-53

World Climate (2006) http://www.worldclimate.com

Yablonsky LT (1995) The material culture of the Saka and historical reconstruction. In: Davis-Kimball J, Bashilov VA, Yablonsky LT (eds) Nomads of the Eurasian steppes in the Early Iron Age. Zinat Press, Berkeley, pp 201-239 